\title{
LINGUISTIC AND CONCEPTUAL FEATURES OF POETIC DISCOURSE
}

\section{Chendey N. V.}

\section{INTRODUCTION}

This article puts forward the study of E. Dickinson's poetic discourse specific features, in particular with a reference to its linguistic and conceptual levels.

Despite the fact that the issue of discourse has been in the central focus of linguists for almost half a century, an abiding scientific interest in this phenomenon seems to be reaching its peak. The explanation leads to a widespread assumption that discourse has no rigid boundaries which in turn causes its ambiguous understanding and interpretations in most linguistic works ${ }^{1}$. Consequently, the study of discourse is heavily conditioned by the approach applied, its methodology and procedures aimed at establishing the most significant features of a given discourse, its common and specific implications.

Poetic discourse is defined as linguistic and mental space created by the author and his/her reader by means of a poetic text that combines three aspects: linguistic, communicative and cognitive ${ }^{2}$.

The linguistic aspect is embodied in a poetic text itself (hereinafter - PT) by thoroughly selected language means that can be perceived sensitively.

The communicative aspect is revealed in a dialogue between the author and reader of a PT in which a poetic function of language prevails and defines the implication of a vast range of linguostylistic devices.

The cognitive aspect deals with the verbalization of artistic concepts. Discourse concepts configuration is defined as a totality of key concepts that belong to various concept fields of a national conceptual sphere and verbalized in a given discourse by linguistic means (A. Pryhodko) ${ }^{3}$.

Thus, it has been hypothetically suggested that stylistic devices (phonetic, lexical, syntactical and textual) provoke triggers in the reader's consciousness, i.e. the verbalization of artistic concepts and their implications

${ }^{1}$ Алефиренко Н. Ф. Текст и дискурс : учеб. пособие / Н. Ф. Алефиренко, М. А. Голованева, Е.Г. Озерова, И.И. Чумак-Жунь. М. : Флинта : Наука, 2012. С. 14-15.

${ }^{2}$ Остапченко В. О. Лінгвокогнітивні та прагмастилістичні властивості лірикопоетичного дискурсу Р. М. Рільке : автореф. дис. ... канд. філол. наук : 10.02 .04 - германські мови / В. О. Остапченко. Харків, 2019. С. 6.

${ }^{3}$ Приходько А. М. Концепти і концептосистеми в когнітивно-дискурсивній парадигмі / А. М. Приходько.Запоріжжя : Прем’єр, 2008. С. 56. 
on the basis of cognitive operations ${ }^{4}$. Correspondingly, triggers are linguistic means of different levels (phonetic, lexical, morphological and syntactical) due to which the artistic concepts and their implications are realized in a discursive context. The term "trigger" has been borrowed from linguistic pragmatics where this term designates a language unit that initiates a definite implicit meaning (S. Levinson) ${ }^{5}$.

In this research the attempt has been made to identify features of poetic discourse in general and to study linguostylistic devices as triggers of some verbal poetic images and artistic concepts in E. Dickinson's lyric-poetic discourse in particular.

\section{The specificity of poetic discourse}

To start with, it is worth mentioning that discourse is commonly defined as a complex communicative phenomenon with its distinctive characteristics. Some scientists describe it as a product of speech act with its inherent semantic homogeneity and relevance to a specific context and genre (Teun A. van Dijk, W. Labov, A. Kybryck, W. Chafe, et al). However, the proponents of the idea that discourse is a verbalized act define it as such that has an inherent connection with culture, a social community and even a historical period (E. Kubryakova) ${ }^{6}$. A broad paradigm of discourse research can be explained by a multidisciplinary approach. Discourse analysis is generally carried out in accord with the main tendencies of cross-discipline approach, vastly employing the methodology and procedures of linguistics, social semiotics, psychology, philosophy, political studies and many others. In addition, discourse is also regarded as a synthesis of the two leading areas - cognitive and communicative ${ }^{7}$.

T. A. van Dijk offers to distinguish discourse in two senses. In a broad sense, discourse is understood as a complex communicative act conducted between a speaker and a listener in a given context. Communicative act can be represented in an oral or written form and it consists of verbal and non-verbal components. In a narrow sense, discourse is a text in an oral or written form, putting a focus solely on a verbal component. Thus, following T. A. van Dijk's assumption, it has been unanimously acknowledged that discourse is a fulfilled or continuous product of communicative act, its oral or written result perceived

${ }^{4}$ Langacker R. W. Concept, Image and Symbol : The Cognitive Basis of Grammar / R. W. Langacker. Berlin, N.Y. : Mouton de Gruyter, 1990. P. 78-80.

${ }^{5}$ Levinson S. C. Pragmatics / Stephen C. Levinson. Cambridge: Cambridge University Press, 1983. P. 50.

${ }^{6}$ Кубрякова Е. С. О понятиях дискурса и дискурсивного анализа в современной лингвистике (Обзор) // Дискурс, речь, речевая деятельность : функциональные и структурные аспекты : Сб. обзоров / Е. С. Кубрякова. М. : ИНИОН РАН, 2000. С. 7.

7 Алефиренко Н. Ф. Текст и дискурс : учеб. пособие / Н. Ф. Алефиренко, М. А. Голованева, Е.Г. Озерова, И.И. Чумак-Жунь. М. : Флинта : Наука, 2012. С. 15. 
and interpreted by the recipients ${ }^{8}$. Analyzing the scholar's approach, the notion of language and its functioning in a given society should be taken into consideration not exclusively from a pragmatic point of view, but also with a special regard to social factors (opinions, attitudes, etc.), He makes a logical conclusion that a speech act is inevitably changeable. It seems apparent that the information in discourse comprises the immediate acts along with the previous states and acts, which become evident in a communicative situation.

In linguistics the term "discourse" has multiple and obscure definitions ranging from its synonymous substitution by utterance, reasoning or speech to the notions of text, dialogue and context.

A famous scholar V. Karasyk defines discourse as a speech practice, a feedback activity between the communicators who exchange both informative messages and emotions. He puts a strong focus on the idea that discourse is based on a mutual impact in which the communicative strategies are interwoven with verbal and non-verbal constituents ${ }^{9}$.

Y. Karaulov extends T.A. van Dijk's assumption and defines discourse as a complex communicative phenomenon that embraces a text itself and a wide range of extralinguistic factors (knowledge about the world, opinions and attitudes), necessary for the message to be comprehended. Metaphorically speaking, discourse is a talk spurt, speech in its constant "movement" that absorbs and reveals historical background, individual and social characteristics of both communicators and a communicative situation itself. Discourse reflects people's mentality and culture on a vast scale and in multiple senses, simultaneously as a national and individual feature ${ }^{10}$. Moreover, discourse is not a mere connection or sequence of sentences, but it is also a semantic unity, characterized by semantic cohesion. Consequently, the notion of discourse is tightly linked with two different approaches that prove to have a crossing point. On the one hand, discourse as a coherent unity represents a flow of speech, a sophisticated syntactic unity that is characterized by a communicative adequacy. On the other hand, discourse touches upon the mental processes of communicators. Here belong ethnic, psychological, social and cultural stereotypes and orientations, along with understanding the strategies, which identify a tempo of speech, a level of coherence, etc.

In the light of major literary studies discourse has been regarded as a macro-structure. For instance, discourse analysis demonstrates the techniques of changing the plot and its reasoning, the motives, genres, etc. Linguistics, on the contrary, dwells on the discourse as a micro-structure, conducting research

${ }^{8}$ Дейк Т. А. ван Язык. Познание. Коммуникация / Т. А. ван Дейк. М. : Прогресс, 1989. С. 45.

${ }^{9}$ Карасик В. И. Языковой круг: личность, концепты, дискурс / В. И. Карасик. М. : Гнозис, 2004. С. 226-232.

1987. C. 124.

${ }^{10}$ Караулов Ю. Н. Русский язык и языковая личность / Ю. Н. Караулов. М. : Наука, 
of syntactic, phonetic, semantic, pragmatic and conceptual features of discourse and their properties. In addition, discourse can be analyzed as a process (a verbalized speech act) or as a result (a fixed text), or both (the two aspects simultaneously) ${ }^{11}$.

The application of discourse analysis and its procedures to the study of poetry has opened new dimensions of a PT, primarily connected with the distinction of two poetic communicators, i.e. "an author" and "a reader". Thus, a reader's reference to a text is perceived as a process of artistic and aesthetic communication between its author and recipient.

L. Vyhotsky defines a poetic discourse as an embodiment of a communicative process, which is obviously a social act. In his opinion, art is a social phenomenon as far as it involves the psychological aspects of perception and experiencing its aesthetic power. Consequently, art serves as a social tool that engages the most intimate and personal domains of our experience in a life social circle ${ }^{12}$.

Poetic discourse as a cultural phenomenon embraces communicative processes that demonstrate linguistic, social and cultural patterns of interaction. These features enable us to refer poetic discourse to anthropologic and sociocultural systems. Meanwhile its vivid aesthetic function provides proof that poetic discourse is an inevitable element of language artistic systems.

Thus, poetic discourse as a systemic formation has its distinctive features:

1. Poetic discourse does not merely reflect the world vision, but proves to be a sense generating and world creating "tool" itself that constructs its own world being a fragment of one of the possible worlds.

2. On the one hand, poetic discourse is the result of the communicators' interaction, and, on the other hand, it proves to emerge in the process of linguistic, social and cultural amalgamation. Therefore, poetic discourse is realized in three dimensions: linguistic, pragmatic (communicative) and cultural.

3. Poetic discourse is a social act whose leading cognitive formations focus on various fragments of an inner world of a linguistic individual. A poetic discourse is a cognitive phenomenon, i.e. it deals with knowledge transmission and procession, new knowledge formation that influences the choice of language means (E. Kubryakova). Thus, a poetic discourse is not a mere text that depicts worlds, but it comprises human's social, cultural and personal experiences (their inner feelings, emotions and thoughts) along with an individual experience (feelings, emotions and thoughts (with)in us) ${ }^{13}$.

${ }^{11}$ Карасик В. И. Языковой круг: личность, концепты, дискурс / В. И. Карасик. М. : Гнозис, 2004. С. 226.

12 Выготский Л.С. Психология искусства / Л. С. Выготский. М.: Рипол Классик, 2016. C. 12.

${ }^{13}$ Алефиренко Н. Ф. Текст и дискурс : учеб. пособие / Н. Ф. Алефиренко, М. А. Голованева, Е.Г. Озерова, И.И. Чумак-Жунь. М. : Флинта : Наука, 2012. С. 57. 
Correspondingly, a complex structure of poetic discourse can be built on different levels of its generalized linguistic, pragmatic, social and cognitive characteristics and further any or all of them can be studied depending on the aim of research and a specific approach applied.

A discursive space in a PT is also described in the following aspects:

1. From the cognitive perspectives discourse is a mental space, i.e. the significant fragment of language individual's consciousness.

2. From the pragmatic (communicative) perspectives discourse is not compressed within the frameworks of a PT, but it is tightly connected with the conditions of its formation, specific aims and tasks.

3. Finally, from the linguocultural perspectives, discourse is a space that is linked with analogical poetic texts (or relevant intertexts) ${ }^{14}$.

The issue of "lyric-poetic discourse" has appeared in the light of recent studies of discourse, dwelling on its specific features. The focus is shifted to the interaction of aesthetic and communicative functions, though the PT architectonics represents an abiding scientific interest. The most significant characteristic features of lyric-poetic discourse prove to be the following:

1. Emotiveness that reflects the author's attitude to the events, facts, emotions and ideas.

2. Homogeneous rhythmic organization created by means of repeated segments of intonation; a key role of prosody; and a rigid compositional structure.

3. The use of semantic and stylistic means is heavily conditioned by the dominant poetic images and poetic genres (elegy, ballade etc.).

4. The use of poetic diction; dependence of emotional and meaningful potential of a word on its place in a rhythmical line.

In addition, poetic discourse is also characterized by such distinctive features as a slow tempo, monotony (evenness of intonation), a rigid system of pauses ${ }^{15}$.

Thus, lyric-poetic discourse is understood as a mental space created by the poet and reader through the prism of a poetic text and it combines three aspects - linguistic (the use of a wide range of stylistic devices), communicative (the dominant poetic function of language) and cognitive (the discursive configuration of artistic concepts). The latter is constructed by means of key concepts that prove to be interconnected. Linguostylistic means play the role of a trigger, which evolves actualization of artistic concepts in the reader's consciousness. Artistic concepts are verbalized by means of phonological, lexical and syntactical stylistic triggers in the process of cognitive operations (various types of repetition and stylistically marked vocabulary) and specifi-

${ }^{14}$ Чернявская В. Е. Интертекстуальное взаимодействие как основа научной коммуникации / В. Е. Чернявская. СПб. : Изд-во СПб. ГУЭФ, 1999. С. 37.

15 Лотман Ю. М. Структура художественного текста. Анализ поэтического текста (структура стиха) / Ю. М. Лотман. М. : Азбука-Аттикус, 2018. С. 345-347. 
cations (parenthesis). Phonostylistic triggers include alliteration, assonance, and paronymic attraction that reinforce the semantics of the word. Lexical-stylistic triggers turn to be different types of lexical repetition (anaphor and epiphora) and stylistically marked vocabulary (religious and artistic terms, biblical expressions, archaisms, poetisms). Syntactic-stylistic triggers (such as syntactic parallelism, antithesis and chiasmus) mark the strong positions in the PT, facilitating the semantic isolation of the lexical units that fill them, which causes the verbalization of artistic concepts ${ }^{16}$.

\section{Conceptual level versus linguistic level in Emily Dickinson's poetic discourse}

\section{Phonological Level}

Poetry possesses a rich oral tradition that anticipates literacy, and much of the ancient poetry was recited or sung. One of the most distinguishing features that differentiate poetry from prose is that the latter is intended to be heard aloud. Imprints of this aspect of poetic history can be found in sound devices such as rhyme, repetition and meter, which are literary devices that are still the most closely associated with the poetic form. How a poem sounds is decisive to how it is perceived, understood and finally remembered. It is noted that the best poets tend to start out with passion, not for ideas or people, but for the possibilities of sound ${ }^{17}$.

Rhyme, meter, rhythm are the main components of the compositional structure of a PT. Generally speaking, poetic composition includes: a) meter (primarily the length of the verse); b) correlation between the syntactic and metric division of speech (the coincidence of the syntactic segment of speech (syntagma) and the verse or their divergence, the emergence of internal pauses and the transference of an incomplete syntagma to the next verse); c) the stanza composition of the poem (astrophic structure (the union of verses into large unities according to their semantic and syntactic characteristics) and the stanza structure whose verses are arranged in stanzas, distinctly separated from each other, with a different number of verses, with a completed syntactic organization); d) the presence or absence of rhyme and rhyming method; e) intonation and rhythmic organization of speech; f) a special poetic syntax (syntactic parallelism of verses and stanzas, a system of repetition of verses and stanzas in the form of anaphora, epiphora, intercepts, refrain, ring construction of stanzas and whole poems). All these components create a unique nature of poetic discourse, which prove to have been incompletely studied so far.

16 Остапченко В. О. Лінгвокогнітивні та прагмастилістичні властивості лірикопоетичного дискурсу Р. М. Рільке : автореф. дис. ... канд. філол. наук : 10.02 .04 - германські мови / В. О. Остапченко. Харків, 2019. С. 6-9.

17 Лотман Ю. М. Структура художественного текста. Анализ поэтического текста (структура стиха) / Ю. М. Лотман. М. : Азбука-Аттикус, 2018. С. 349. 
It is important to mention that any discourse represents the so-called code. It means that the author decodes meanings of the poetic content. The task of the reader involves perception of linguistic and extra linguistic elements in a PT in order to decipher them. In addition, a reader not merely decodes the message of the PT itself, but also seeks for his/her personal relation to the author or at least their mutual touching points.

The sequence of symbols in poetic speech creates the unity of metamorphoses due to the models of specific poetic structures. Among them are, for instance, phonic or metric-rhythmic structures. The overall image of the author and uniqueness of his/her manner of writing are perceived through the prism of poetic language. However, it seems important to determine the connection between poetic language and literary language with its normative basis. The poetic language arises from the real word, used in both literary and national language, after which it absorbs a certain motivation and fulfills a certain artistic function.

Phonetic stylistic devices such as alliteration, assonance, consonance and caesura are considered to be triggers of the verbal poetic images and artistic concepts in E. Dickinson's poetic discourse.

Alliteration is defined as the use of two words or more in close proximity that begin with the same consonant sound. Emily Dickinson uses alliteration in her poem "Fame is a fickle food" to actualize FAME that ultimately destroys whoever "eats" it. "Fame is a fickle food Upon a shifting plate Whose table once a Guest but not The second time is set. Whose crumbs the crows inspect". Alliteration is used in the first line of each stanza in the poem to emphasize FAME and its fleeting, entirely unpredictable nature. Using the lexemes "fame" and "fickle food" deeply accentuates the fact that while these notions can hardly be associated, they create a context for realizing the verbal poetic image of fame that fades away. This is highlighted by the next three lines in the stanza "Whose table once a Guest but not The second time is set", which literary means that fame is unstable. Alliteration adds to an empty and lamented tone of the poem, being intensified by the irony in the caw and crows that are smart enough to figure out that fame, unlike corn, is not filling, nourishing. Humans, however, take fame over worthwhile things, which makes them lose sights of their former selves ${ }^{18}$.

Consonance refers to repetitive sounds produced by consonants within a sentence or phrase. This stylistic device may be exemplified by the lines in which Emily Dickinson has made use of the consonant $/ \mathrm{m} /$ frequently in the underlined words: "Twas later when the summer went/ Than when the Cricket

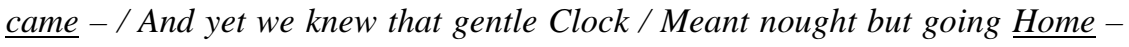

${ }^{18}$ Alliteration Examples and Definition - Literary Devices http://www.literarydevices.com/ alliteration/. 
Twas sooner when the Cricket went/ Than when the Winter came / Yet that pathetic pendulum Keeps esoteric Time".

The poetess generally makes use of consonance in an attempt to underscore the emotions behind her words that simple words cannot convey. Another poem by Dickinson that makes good use of consonance is “As imperceptibly as Grief”. "A Quietness distilled As Twilight long begun, Or Nature spending with herself Sequestered Afternoon". Here Emily Dickinson has relied on the consonant " $n$ " to create the intended effect. The poem is a deceptively simple meditation on the nature of TIME. It compares grief to summer, suggesting that people don't always notice the way that everything undergoes gradual change - but nothing in life stays still. The poetic image of DEATH is implicitly felt as the poem gently reminds the reader that LIFE is fleeting - the passage of TIME eventually brings all life to its inevitable end, but it does it so gradually, in a way similar to the returning of summer into autumn.

Alliteration occurs at two moments in "As imperceptibly as Grief”. It is first used in line 9 with "dusk drew", both beginning with /d/ sounds. The effect is subtle but it conjures the idea of the day being covered with darkness. Lines 11 and 12 then feature three /g/ sounds "grace" "guest" and "gone". This links the three words together conceptually, and as they are the main examples of /g/ create a sense of presence that is absent elsewhere. This embodies the idea of something or someone arriving, and then departing. The /g/ sound here echoes its first appearance in line 1 - "grief". The idea of departure becomes linked to the feeling of loss, supporting the poem's overall proposition that loss is everywhere in everyday reality - nothing can last forever.

Emily Dickinson's poem, “I heard a Fly buzz - when I died”, is told by a woman who is still speaking and still hearing things upon her death. The alliteration of /st/ connects the words "stillness" and "storm". Conceptually, these two words are at odds, and yet in context Dickinson is referring to the calm that occurs in the middle of storms, such as the eye of the hurricane. The stillness at those times is more profound that at other times, and this connection between stillness and storm is highlighted by her use of alliteration.

Caesura is a rhythmic break or pause in the flow of sound which is commonly introduced in about the middle of a line of verse, but may be varied for different effects. Typically placed between syllables, rhythmically connected in order to aid the recital as well as to convey the meaning more clearly, it is a pause dictated by the sense of the content or by natural speech patterns, rather than by metrics. It may coincide with conventional punctuation marks, but not necessarily. A caesura within a line is indicated in scansion by the parallel symbol $(\|)$, as in the first line of Emily Dickinson's "I'm Nobody! Who Are You?”: I'm no | body! || Who are | you? As a grammatical, rhythmic, and dramatic device, as well as an effective means of avoiding monotony, the caesura is a subtle but effective weapon in the skilled poetess's arsenal. 


\section{Morphological level}

E. Dickinson experiments with coining new words, which facilitates the uniqueness of her poetic discourse. The examples point to the author's manipulating grammar rules, when the verb is used as a noun: "I need no further Argue - That statement of the Lord Is not a controvertible - He told me, Death was dead"

In the poem "Book" Emily Dickinson uses the verb "oppress" as a noun, for instance: "This traverse may the poorest take Without oppress of toll; How frugal is the chariot That bears a human soul!"

Another example illustrates the formation of the derivative with the help of the suffix -less which is attached to the stem of the verb by the author. This suffix is usually fixed to the stem of the noun, for example: "Is an unfurnished Circumstance Possession is to One As an Estate perpetual Or a reduceless Mine"

Emily Dickinson prefers new forms of pronouns and verbs in almost all her poems, however, in her love lyrics, she interchangeably uses old and new forms, for example: "Why do I love" You, Sir? ... The Sunrise-Sire-compelleth Me- Because He's Sunrise-and I see- Therefore-Then-I love Thee-". E. Dickinson experiments with coining new words which facilitates the uniqueness of her poetic idiostyle.

\section{Syntactic level}

In the plane of syntax, Emily Dickinson's poems contain a large number of inversions which favours the additional semantic load on the lexical elements, for example: "Of bumble-bees and other nations / The grass is full", "High from the earth I heard a bird". Another example is as follows: "Conscious am I in my Chamber, / Of a shapeless friend -", "Though can'st not boast, like Jesus, drunken without companion / Was the strong cup of anguish brewed for the Nazarene", etc.

We can observe the innovative approach to inversions in the texts of the poetess, which are constructed on the basis of placing the elements of syntagmas with largest semantic content in the initial position in a sentence, which is employed to achieve the effects of novelty and unexpectedness: "One Sister have I in our house", "Of nearness to her sundered Things / The Soul has special times -", "Warm in her Hand these accents lie", "I Years had been from Home", etc.

This method creates an effect of importance for understanding metaphors through iconicity; one of the principles of embodiment is the localization of priority items at the beginning of the sentence.

Some Dickinson's poems are characterized by clear syntactic construction using parallel structures, regarded as "the dominant principle of parallelism": "Where I have lost, I softer tread - / [...] / Whom I have lost, I pious guard / [...] / When I have lost, you'll know by this $-/[\ldots]$ / Why, I have 
lost, the people know", "On such a night, or such a night, / Would anybody care / [...] / On such a dawn, or such a dawn - / Would anybody sigh”.

In addition to complementary rhythmic effects, this method can serve as the key to understanding "non-grammatical" sentences of E. Dickinson since it guides the reader to find common associations between these fragments and the relationship with the concepts available in them.

The antithesis is one of the stylistic devices that are essential to the idiostyle of E. Dickinson. The characteristic feature of the poetess is the usage of denial and refusal, as well as sharply expressed antithesis. Her texts impress by specific narrative perspective where events either never occur, as in the examples: "By those who ne'er succeed", "Who never lost, are unprepared", "I never hear the word "escape", or it is impossible or there is no desire/ opportunities to perform an action: "I could not have told it", "I shall not fear mistake -". The above-mentioned and many other statements of objections and negative constructions is another feature of Dickinson's poetics.

Enumeration is another syntactic expressive means which consists in naming over various qualities or recounting different objects or actions with the purpose of giving a multidimensional artistic characteristics to the phenomenon described. The words enumerated are homogeneous parts of a sentence: "Nature is what we hear- The Bobolink-the Sea-Thunder-the Cricket -". Enumeration makes the poems more impressive and enables the author to stress the exact place in the text space that needs on the reader's part to be noticed, perceived and interpreted.

\section{Lexical level}

The lexical content of E. Dickinson's poetic texts is unique. The inner world of the poetess is extremely rich due to its formation under the influence of nature, whose many phenomena are embodied in her poems. These include:

- a volcano: e. g. "A still - Volcano - Life -";

- the moon and sea: e.g. "The Moon is distant from the Sea -";

- bees: e.g. "Like Trains of Cars on Tracks of Plush / I hear the level Bee -";

- butterflies: e.g. “The Butterfly's Numidian Gown”,

- birds: e.g. "The most triumphant Bird I ever knew or met".

These images of the surrounding world and nature are dominant in Dickinson's poetic heritage and create linguistic and conceptual levels of her poetic discourse. The analysis done provides evidence that Emily Dickinson's poetic lexicon contains the most frequent lexemes that serve the function of key PT dominants.

As it is seen, the 12 most frequent text dominant lexemes lay the conceptual foundation of E. Dickinson's poetic texts. Their discursive configuration and metaphorization construct the conceptual system that defines the uniqueness of Dickinson's poetic style. The artistic concepts of SUN, GOD, SOUL, HEART, NIGHT, LOVE, BIRD, EYES, BEE, LIGHT and SKY prove to be the core elements in the poetess's artistic picture of the world. 
Dominant key words and their distribution in E. Dickinson's poetry

\begin{tabular}{|c|c|c|l|}
\hline Frequency & Lexeme & Percentage & \multicolumn{1}{|c|}{ Examples } \\
\hline 66 & sun & $14 \%$ & $\begin{array}{l}\text { We passed the Fields of Gazing Grain - } \\
\text { /We passed the Setting Sun - }\end{array}$ \\
\hline 57 & death & $12,1 \%$ & $\begin{array}{l}\text { Does the dark gate of death / Conduct to } \\
\text { thy mysterious paradise, / O Sleep? }\end{array}$ \\
\hline 53 & god & $11,3 \%$ & $\begin{array}{l}\text { As if that frail and wasted human form, } \\
\text { /Had been an elemental god. }\end{array}$ \\
\hline 48 & soul & $10,2 \%$ & $\begin{array}{l}\text { That shone within his soul, he went, } \\
\text { pursuing /The windings of the dell. }\end{array}$ \\
\hline 46 & heart & $9,8 \%$ & $\begin{array}{l}\text { Nor ever more offer at thy dark shrine / } \\
\text { The unheeded tribute of a broken heart. }\end{array}$ \\
\hline 33 & night & $9,1 \%$ & $\begin{array}{l}\text { In lone and silent hours, /When night } \\
\text { makes a weird sound of its own stillness, / } \\
\text { Like an inspired and desperate alchymist }\end{array}$ \\
\hline 33 & bird & $7,8 \%$ & $\begin{array}{l}\text { Your love, and recompense the boon with } \\
\text { mine; / If dewy morn, and odorous noon, } \\
\text { and even }\end{array}$ \\
\hline 27 & eyes & $5,7 \%$ & $\begin{array}{l}\text { If no bright bird, insect, or gentle beast / } \\
\text { I consciously have injured, but still loved }\end{array}$ \\
\hline 18 & bee & $\begin{array}{l}\text { And virgins, as unknown he passed, have } \\
\text { pined / And wasted for fond love of his } \\
\text { wild eyes. }\end{array}$ \\
\hline 19 & light & $\begin{array}{l}\text { Fame is a bee. It has a song- / It has a } \\
\text { sting-/Ah, too, it has a wing. }\end{array}$ \\
\hline sky & $3,8 \%$ & $\begin{array}{l}\text { And all the shows o' the world are frail } \\
\text { and vain / To weep a loss that turns their } \\
\text { lights to shade. }\end{array}$ \\
\hline $\begin{array}{l}\text { The sky, the Poet kept mute conference / } \\
\text { With his still soul. At night the passion } \\
\text { came }\end{array}$ \\
\hline
\end{tabular}

The issue of poetic formulas has been in the prime focus of recent discourse studies. However, the question remains open due to the ambiguity of definitions and their interpretations. Thus, along with the term 'poetic formula" in most linguistic research, one can come across the terms "poetic phraseology”, "paraphrase”, "paraphrase expression”, "descriptive metaphoric combination", "poetic cliché", "traditional poetic combination", "metaphoric combination", et al.

Poetic formulas are specific phenomena of poetic discourse, characterized by some basic image which is tightly connected with the system of traditional images found in poetry of various writers at different times. Generally speaking, poetic formulas are metaphoric expressions, based on the 
semantic universals, called archetypes. They are believed to be the world vision creative images ${ }^{19}$ Some of them are life is a movement, death is a dream, the world is a theatre, etc.

Being a model of concepts interaction, a metaphor forms an inseparable unity with the author's conceptual system. On the one hand, to study the mechanisms of metaphor creation and function it is necessary to consider the author's conceptual system. On the other hand, the research of metaphoric nomination can serve the basis for the study of this system organization and principles of its modeling.

DEATH is one of the key artistic concepts in E. Dickinson's poetry. However, its metaphors represent different images, which are never repeated. The most frequent proves to be a metaphor DEATH IS A DEPARTURE that undergoes various modifications, demonstrating the poetess's world vision. "Because I could not stop for Death - He kindly stopped for me - The Carriage held but just Ourselves - And Immortality". A poetic metaphor DEATH IS A COACHMAN is made through a conceptual mechanism of restriction and death personification (the usage of a pronoun $\mathrm{He}$ ). The image of "The Carriage held just Ourselves - and Immortality" implies the meaning of a departure with no return. And it is a natural way we perceive of death. As G. Lakoff and M. Turner fairly state that when we read "Because I could not stop for Death -" and understand that what the speaker could not stop are her purposeful activities, we can understand those purposes as destinations and her life as a journey to reach those destinations. The occurrence of the word "Death" in the line suggests the reading that what she declines to stop is her life's journey. The second line, "He kindly stopped for me", and the occurrence of "Carriage" in the third line make it clear that what is being talked about is a journey. Thus, LIFE IS A JOURNEY with a stopping point and that stopping point is DEATH'S departure point. Consequently, DEATH IS A JOURNEY with a destination ${ }^{20}$.

In E. Dickinson's poetry LIFE is conceived of in terms of bodily BONDAGE. The soul of a person leading the life is metaphorically a bound prisoner. Thus, LIFE can be said to imprison the soul in the body. The event of DEATH is metaphorically the event of being released from imprisonment. "Afraid? Of whom am I afraid? Not Death, for who is He? The porter of my father's lodge As much abasheth me...". This example illustrates the image of DEATH that is metaphorically presented as an escape and a comfortable shutter for a soul. "My father's lodge" is home and the soul's final resting place and "the porter" who ushers you into that home is DEATH personified.

19 Алефиренко Н. Ф. Текст и дискурс : учеб. пособие / Н. Ф. Алефиренко, М. А. Голованева, Е.Г. Озерова, И.И. Чумак-Жунь. М. : Флинта : Наука, 2012. С. 83.

${ }^{20}$ Lacoff G., Turner M. More than cool reason: a field guide to poetic metaphor / G. Lacoff, M. Turner. Chicago : University of Chicago Press, 1989. P. 4. 
To sum up, the totality of inner and outer factors (cognitive, linguistic and extralinguistic) stimulates the triggers in PT space and specifies the conceptual content of verbal poetic images, their conceptualization and perception.

\section{CONCLUSIONS}

The system of poetic discourse is the unity of process and its result (talk and text by van Dijk 1997), a communicative act (Karasyk 2002), which is determined as a discourse formation and perception. Thus, poetic discourse comprises two aspects, namely dynamic and static. The basis for a PT interpretation as a two-dimensional process proves to be the universal characteristics of creative activity and its perception. Correspondingly, the underlying mechanism of a textual act as a two-facet process is defined by its perception (from the perspectives of both the author and reader).

Having considered linguistic and conceptual features of Emily Dickinson's poetic discourse, we have concluded that it is unique due to the poetess' cognitive style which proves to be deprived of biased traditional canons, but through the self-isolation provides the non-canonical view of spiritual values which find expression in the conceptual content of most poetic images. The prevalence of emotiveness and accuracy of key images put a prime focus on reader's perception and sensitive experience.

However, imagery of Emily Dickinson's poetic discourse is heavily conditioned by frequent violations of generally accepted norms (a vast range of inversions and ellipsis), compensated by the frequency of their use. Parallel structures (including anaphora and epiphora), antithesis, comparison and gradation serve as the key stylistic devices that determine the specificity of E. Dickinson's poetic discourse. Accordingly, her individual syntactic and compositional patterns laid the foundation for generating new verbal poetic images and artistic concepts.

The "fragmentation" of speech and saturation of poems with dashes contribute a lot to deepen the semantic content, encouraging the reader to experiment with the vision of verbal poetic images owing to the reconstruction of missing elements of sentences and his/her readiness to tie the notion with a sensitively perceived object. Thus, an image is a nucleus component of an artistic concept structure, without which the latter cannot function as a discrete unit of thought and interact with other concepts.

Metaphor also represents an instance of a conceptual interaction in E. Dickinson's poetic discourse. It is frequently used to designate a new concept or enrich an old one by drawing an analogy between new entities. An image can serve as an activator of consciousness information state when one concept can provoke or implicate another concept. This seems to be discursive concepts' modeling potential. 
In addition to the universal metaphors that serve the function of poetic formulas in discourse, it is possible to reconstruct individual poetic metaphors ("life is a journey by sea", "death is an integral part of existence"). A poetess designs different figurative images while touching upon language. They are tightly linked by her world vision. An analogy in metaphor is not a mere search for similarities in objects, events or phenomena, but it directly refers to the author's cognitive, creative aspiration and worldview.

Emily Dickinson puts to the fore the idea of "imperceptible nature". It becomes obvious that the originality of her poetic discourse is crafted by filling the conceptual space of PTs with zoological and floristic images (birds, bees, caterpillars, butterflies, flowers, et al), providing a solid proof of the nature's exceptional role and a significant impact on the formation poetess' artistic world vision and style.

\section{SUMMARY}

Poetic discourse is characterized by a range of important features that distinguish it from other discourses, namely a high degree of metaphor saturation, the measured rhythmic-syntactic text segmentation and a vast range of phonetic means. Moreover, the logical structure of the poetic text is rather rarely defined by the linearity, typical of prose; instead there prove to be numerous violations of the sequence of events or thoughts. Stylistic devices (phonetic, lexical, syntactical and textual) provoke triggers in the reader's consciousness due to which the artistic concepts and their implications are verbalized in a discursive poetic context. The prevalence of these features determines the most significant characteristics of poetic discourse with its prime focus on the aesthetic influence on a listener / reader. Thus, poetic discourse study dwells on different stages of an artistic text functioning cycle: the author (an individual concept sphere) - the artistic reality (a conceptual text structure) - the reader (cognitive mechanisms of perception) as well as the interconnection between all of them.

\section{REFERENCES}

1. Алефиренко Н. Ф. Текст и дискурс : учеб. пособие / Н. Ф. Алефиренко, М. А. Голованева, Е.Г. Озерова, И. И. Чумак-Жунь. М. : Флинта : Наука, 2012. 232 с.

2. Выготский Л.С. Психология искусства / Л. С. Выготский. М.: Рипол Классик, 2016. 528 с.

3. Дейк Т. А. ван Язык. Познание. Коммуникация / Т. А. ван Дейк. М. : Прогресс, 1989. 308с.

4. Карасик В. И. Языковой круг: личность, концепты, дискурс / В. И. Карасик. М. : Гнозис, 2004. 390 с.

5. Караулов Ю. Н. Русский язык и языковая личность / Ю. Н. Караулов. М. : Наука, 1987. 264 с. 
6. Кубрякова Е. С. О понятиях дискурса и дискурсивного анализа в современной лингвистике (Обзор) // Дискурс, речь, речевая деятельность : функциональные и структурные аспекты : Сб. обзоров / Е. С. Кубрякова. М. : ИНИОН РАН, 2000. С. 7-25.

7. Лотман Ю. М. Структура художественного текста. Анализ поэтического текста (структура стиха) / Ю. М. Лотман. М. : АзбукаАттикус, 2018. 704 с.

8. Остапченко В. О. Лінгвокогнітивні та прагмастилістичні властивості лірико-поетичного дискурсу Р. М. Рільке : автореф. дис. ... канд. філол. наук : 10.02.04 - германські мови / В. О. Остапченко. Харків, 2019. 20 c.

9. Приходько А. М. Концепти і концептосистеми в когнітивно-дискурсивній парадигмі / А. М. Приходько. Запоріжжя : Прем’єр, 2008. 331 с.

10. Чернявская В. Е. Интертекстуальное взаимодействие как основа научной коммуникации / В. Е. Чернявская. СПб. : Изд-во СПб. ГУЭФ, 1999. 264 c.

11. Dickinson E. The Selected Poems by Emily Dickinson / E. Dickinson. Hertfordshire : Wordsworth Editions Ltd, 1994. 214 p.

12. Lacoff G., Turner M. More than cool reason: a field guide to poetic metaphor / G. Lacoff, M. Turner. Chicago : University of Chicago Press, 1989. $230 \mathrm{p}$.

13. Langacker R. W. Concept, Image and Symbol : The Cognitive Basis of Grammar / R.W. Langacker. Berlin, N.Y. : Mouton de Gruyter, 1990. 546 p.

14. Levinson S. C. Pragmatics / Stephen C. Levinson. Cambridge: Cambridge University Press, 1983. 420 p.

\section{ELECTRONIC RESOURCES}

15. Alliteration Examples and Definition - Literary Devices http://www.literarydevices.com/alliteration/.

16. As imperceptibly as grief Poem Summary and Analysis | LitCharts https://www.litcharts.com/poetry/emily-dickinson/as-imperceptibly-as-grief.

\section{Information about the author: Chendey N. V.,}

Candidate of Philological Sciences in Comparative Linguistics, Associate Professor at the Department of English Philology

Uzhhorod National University 14, office 539, Universytetska str., 88000,

Uzhhorod, Zakarpattia region 